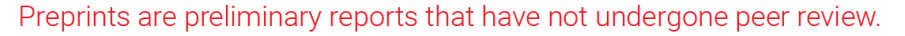 They should not be considered conclusive, used to inform clinical practice, or referenced by the media as validated information. \\ The Impact of Land Use and Land Cover Changes on Soil Erosion in Western Iran
}

\author{
Hadi Eskandari Damaneh \\ Hormozgan University \\ Hassan Khosravi ( $\nabla$ hakhosravi@ut.ac.ir) \\ University of Tehran https://orcid.org/0000-0002-2594-6199 \\ Khalil Habashi \\ Shahid Chamran University of Ahvaz \\ Hamed Eskandari Damaneh \\ University of Tehran \\ John P. Tiefenbacher \\ Texas State University
}

\section{Manuscript}

Keywords: Maximum Likelihood, NDVI, RUSLE, Landsat, Shadegan Wetlands

Posted Date: February 11th, 2021

DOl: https://doi.org/10.21203/rs.3.rs-185452/v1

License: (c) (1) This work is licensed under a Creative Commons Attribution 4.0 International License. Read Full License 


\title{
The impact of land use and land cover changes on soil erosion in western Iran
}

\author{
Hadi Eskandari Damaneh ${ }^{1}$, Hassan Khosravi*2 Khalil Habashi $^{3}$, Hamed Eskandari Damaneh ${ }^{2}$, \\ John P. Tiefenbacher ${ }^{4}$
}
1. Faculty of Agriculture and Natural Resources, University of Hormozgan, Bandar Abbas, Iran
2. Department of Arid and Mountainous Regions Reclamation, Faculty of Natural Resources, University of Tehran, Tehran, Iran
3. Faculty of Remote Sensing and GIS, Department of Earth Sciences, Shahid Chamran University of Ahvaz, Ahvaz, Iran

4. Department of Geography, Texas State University, San Marcos, Texas, USA

\section{*Corresponding Author: hakhosravi@ut.ac.ir}

\section{Abstract}

Estimates of long-term change and land cover changes using satellite imagery update data about effects erosion on the destruction. This is relevant on semi-arid land where soil resources are scarce, and proper management requires matching LULC to the conditions to achieve sustainability. This study evaluates the impact of LULC changes on soil erosion using Landsat satellite images and the RUSLE model on plains around the Jarahi River and Shadegan International Wetlands. The maps of LULC were prepared with supervised classification and maximum-likelihood methods applied to pre-processed TM, ETM, and OLI images for 1989, 2003, and 2017. This study investigated the impacts of LULC changes on soil erosion. Based on the results, we observe that an assessment of LULC changes from 1989 to 2003 revealed diminishing bare land and wetland vegetation with increases in agricultural land and water features. The areas of agricultural lands and wetlands decreased from 2003 to 2017, while bare lands increased in the area. The areas with soil erosion rates $<1 \mathrm{Mg} \mathrm{ha}^{-1} \mathrm{y}^{-1}$ have diminished, and areas having rates $>1 \mathrm{Mg} \mathrm{ha}^{-1} \mathrm{y}^{-1}$ increased in extent. We conclude that LULC changes led to increased soil erosion in Shadegan International Wetlands. Our study highlights the need to plan LULC changes to reduce soil erosion rates to achieve sustainable management. We argue that nature-based solutions can effectively reduce soil losses. Keywords: Maximum Likelihood, NDVI, RUSLE, Landsat, Shadegan Wetlands

\section{1. Introduction}


33 Changing land uses and land covers (LULCs) are the primary environmental change responsible

34 for global change (Guan et al., 2011). Most of these changes are due to human activities like deforestation, urbanization, intensive agriculture, and overgrazing, which subsequently lead to land degradation. Natural changes can, however, lead to LULC changes, too (Lambin, 1997). Intensive agriculture and excessive livestock grazing are significant triggers for desertification and land degradation in arid regions (Daliakopoulos et al., 2016). Insensitive and fragile areas, land degradation, and desertification reduce production capacities of different land uses (Eskandari et al., 2016); there is a need for better approaches to management.

Controlling soil erosion is crucial for achieving sustainable development goals. Clark and Dickson (2003) highlighted the need to develop sustainability science to facilitate a path to sustainable societies. Sachs and McArthur (2005) advanced the millennium project to develop millennium development goals. Griggs et al. (2013) addressed sustainable development to achieve the sustainability of humanity in the context of Earth's limits, and this resulted in the development of the Sustainable Development Goals (SDGs) of the United Nations. Keesstra et al. (2016) clarified the importance of soil management, erosion, prevention, and land-degradation neutrality (Keesstra et al., 2018) to promote sustainability and to achieve the SDGs Anthropogenic LULC changes can destroy natural resources and affect food supplies to the extent that they may cause severe social and political consequences (Khosravi et al., 2017; Turner et al., 2007). Most studies have focused only on LULC changes, with little attention to the relationships between land use change and other environmental impacts (Xiao et al., 2006, Rawat, and Kumar,2015, Hegazy et al., 2015), particularly the relation of land use change to soil erosion. In general, scientists expect soil erosion to result in inappropriate use of land, which can accelerate soil erosion (Chen, 2008). Several studies have recently concentrated on the environmental effects of soil erosion, reviewing the long-term impacts of soil erosion, including soil fertility, reduced crop yields, decreased soil quality due to nutrient loss, adverse impacts of pesticide use, and heavymetal contamination of surface water (De Wit and Behrendt, 1999; Verstraeten et al., 2002). Land use change is among the main factors driving soil erosion, and it is intensified by human activities (Houben et al., 2006). It seems necessary to examine the potential impacts of this type of erosion locally and regionally. It is one of the most pressing environmental issues that not only diminishes soil fertility but is also tied to other non-soil problems like flooding, salinization, and water contamination (Rickson, 2014; Xiubin and Juren, 2000). 
Water erosion defined as the soil materials separation, movement, and damage by mean of water.

65 This process maybe occurs natural or intensify by human interventions. Erosion rates can change from very low to very high, depending on the soil properties, and environmental and climatic conditions. Soil erosion is a severe threat to the sustainability of resources, communities, and the environment. Therefore, evaluating and monitoring soil erosion is critical. Soil erosion and its consequences (soil loss, slope instability, and reduced fertility) are highly dependent on land use management (Bini et al., 2006). Several studies have shown a strong correlation between land use change and soil erosion (Mutua et al., 2006; Sharma et al., 2011). Assorted models have been used to calculate soil erosion (average long-term soil losses) and among them is the Revised Universal Soil Loss Equation (RUSLE) (Renard et al., 1997). The RUSLE model calculates the maximum amount of allowable soil loss from a specific soil type before maximum sustainable yield of an area is diminished (Ranzi et al., 2011). It can also be used to determine appropriate land use systems and necessary preventative and mitigative practices (Ranzi et al., 2012; Zare et al., 2017).

Studies have examined the impacts of land use changes on annual erosion rates using the USLE model - in the Emilia-Romagna highlands of north-central Italy (Brath et al., 2002) - and the RUSLE with GIS - in the Wadi Karaka watershed of Jordan (Farhan and Nawaiseh, 2015). Isaaca and Aqelel Ashraf (2017) reviewed the effects of erosion and land degradation on water quality and concluded that erosion generates significant adverse impacts on water quality. Sharma et al. (2011) studied the effects of LULC changes on erosion potential in agricultural lands (Sharma et al., 2011), and Tadesse et al. (2017) assessed erosion impacts from LULC change in northeastern Ethiopia (Tadesse et al., 2017). Zare et al. (2017) used RUSLE and the Conversion of Land Use and Its Effects at Small Regional Extent (CLUE-s) model to examine scenarios of land use change and their impacts on soil erosion in the Cazilan watershed, Iran.

87 Considering the importance of agriculture in the Shadegan wetland of Iran, the high susceptibility of the ecosystem to environmental change, and the emergence of airborne dust in the region, this research examines the relationships of LULC change to soil erosion in this region using GIS techniques and remote sensing. The research is secondarily intended to produce useful information for managers and decision-makers who seek to find appropriate management solutions and conservation practices to combat erosion in the region.

\section{Materials and Methods}




\subsection{The study area}

The study area is in Khuzestan Province, Iran, and encompasses the plains around the Jarahi River in Ramshir and Shadegan counties and the Shadegan International Wetland. The region is circumscribed by a box with lines drawn at $30^{\circ} 19^{\prime}$ and $30^{\circ} 51^{\prime} \mathrm{N}$ and at $48^{\circ} 41^{\prime}$ and $49^{\circ} 43^{\prime} \mathrm{E}$, an area of 299,000 ha (Figure 1). As the $11^{\text {th }}$ longest river in Iran (438 km long), the Jarahi River flows through Kohgiluyeh and Boyer-Ahmad Province and Khuzestan Province. Shadegan International Wetland is located at the downstream end of the Jarahi River on the Khuzestan Plain in the Jarahi River delta. Shadegan is the home of permanent and seasonal hydrophilic and mesophilic vegetation. the halophilic plants dominate in the area surrounding the swamp except in areas of palm orchards and agricultural lands. The four main species are Cyanus longus (covering about $70 \%$ of the wetland area), Typha minima (about 15-20\%), Salsola sp (about 10\%), and Phragmites $s p$ (about 5\%) (Rahimi Blouchi et al., 2013). The highest and lowest elevations in the study area are $59 \mathrm{~m}$ and $3 \mathrm{~m}$. The slope angles of the highest and lowest frequencies are $0 \%$ and $60 \%$, respectively.

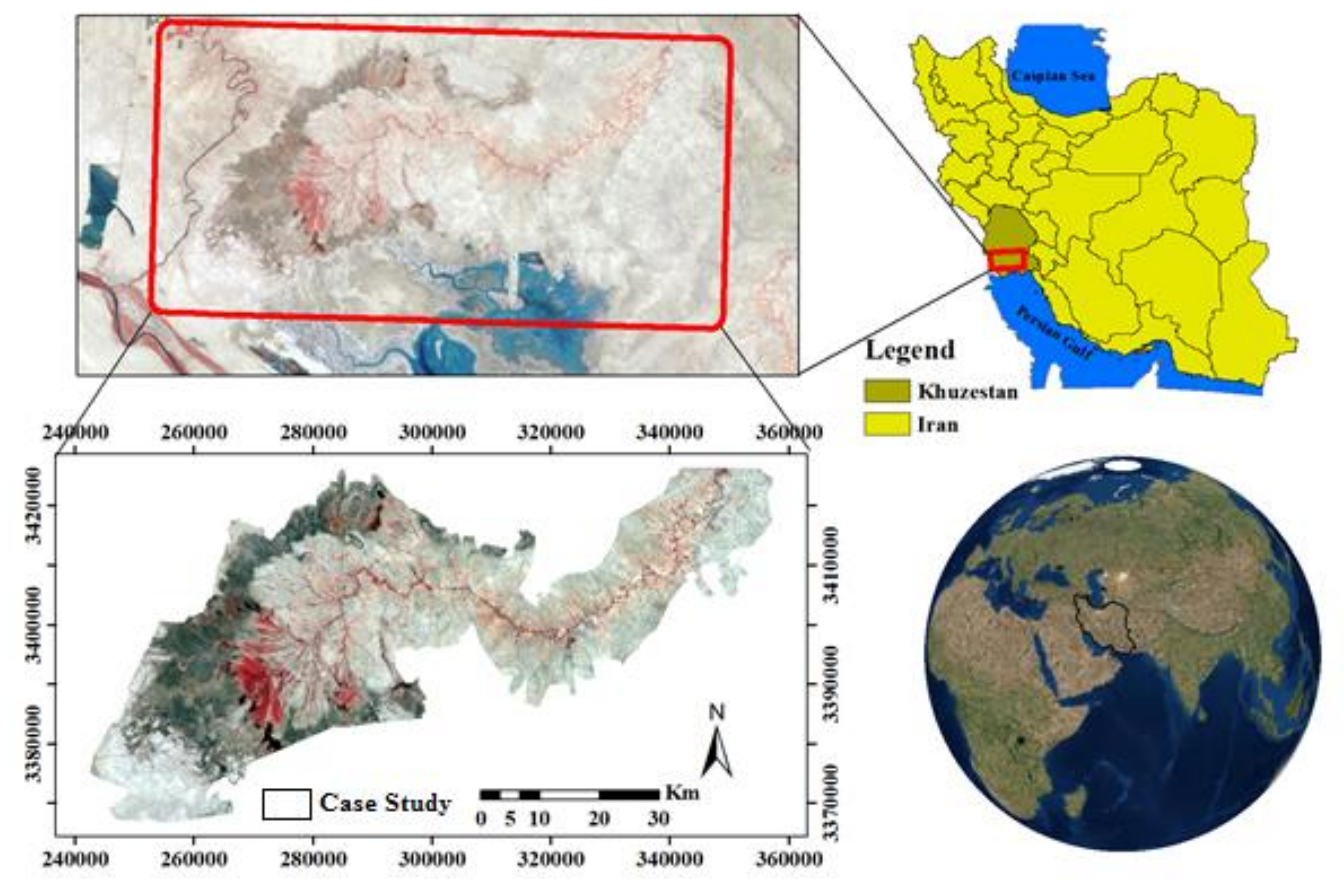

Figure 1. Location of the study area

\section{2. Data}

Satellite data for the study area (path and row 165 and 39) were compiled from Landsat 5, the TM sensor (on June 3, 1989), Landsat 7, the ETM sensor (on May 29, 2003), Landsat 8, and the OLI 

sensor (May 23, 2017). A digital elevation model (DEM) from ASTER data at a $30 \times 30 \mathrm{~m}$ resolution

115 was also acquired. These data were accessed from the USGS website 116 (www.earthexplorer.usgs.gov). The digital elevation model (DEM) is necessary for providing the 117 digital Earth. Nowadays, there are two set of near-global DEM produced by mean of remotely 118 sensed data. One is the elevation data-set produced using the C-band single-pass Interferometry 119 Synthetic Aperture Radar (InSAR) data obtained by the Shuttle Radar Topography Mission 120 (SRTM) covering between $56^{\circ} \mathrm{S}$ to $60^{\circ} \mathrm{N}$ latitudes. The other is the Global Digital Elevation Model 121 produced by the stereo processing of the Advanced Space borne Thermal Emission and Reflection 122 Radiometer Global Digital Elevation Model (ASTER GDEM) covering the earth's land surface 123 between $83^{\circ} \mathrm{N}$ and $83^{\circ} \mathrm{S}$ latitudes ( $\mathrm{Ni}$ et al., 2015). A 1:250,000-scale topographic map, a map of 124 soil texture, and climatic data (1989-2017) were acquired from Iran's National Cartographic Center, 125 the Agricultural Research Center of Khuzestan Province, and the Khuzestan Meteorological 126 Organization, respectively. The layers were created and merged using ERDAS IMAGINE and 127 ArcGIS software.

\subsection{Pre-processing of satellite imagery}

130 A geometric correction was applied to the satellite data to facilitate ground accuracy. The TM and 131 ETM sensor data were georeferenced to the OLI in plural using the image-to-image technique with an RMSE of less than 0.5 pixels. Since changes in illuminance affect the radiation intercepted by 133 a pixel, atmospheric corrections were also applied. The ATCORE extension in ERDAS IMAGINE 1342014 software and the metadata file associated with the satellite imagery was used to the atmospheric corrections.

\subsection{Preparing land-cover maps}

138 Google Earth images, aerial photographs, for periods 1989 and 2003, and GPS point locations 139 captured in the field for period 2017 were used to select training samples to carry out a supervised 140 classification. To recognize the type of land cover, samples were randomly choosing from specified area using the Region of Interest (ROI) tool provided by ERDAS IMAGINE 2014 software with

142 helping of the Google Earth tool and ground data. Half of the sample pixels were randomly selected 143 as training samples, and the remaining half was used for classification accuracy assessment. The 144 total sample pixels used for the classification accuracy estimation were 80 pixels for agricultural 
145 lands, 200 pixels for bare lands, 50 pixels for bare land, 40 pixels for wetlands, 60 pixels for forest

146 and 2365 pixels for the wetland vegetation, 40 pixels for urbanized areas

147 The maximum likelihood algorithm (Ozesmi and Bauer, 2002; Gumel et al., 2020,) was used for

148 classification in ERDAS IMAGINE 2014. This method is based on the probability that a pixel

149 belongs to a particular class. The basic theory assumes that these probabilities are equal for all

150 classes and that the input bands have normal distributions. However, this method needs long time

151 of computation, relies heavily on a normal distribution of the data in each input band and tends

152 to over-classify signatures with relatively large values in the covariance matrix. An appropriate

153 band combination was identified for classification by selecting evaluate in the signature editor

154 menu based on the best average. Band combinations were used for classification of data obtained

155 from the TM, ETM, and OLI sensors, respectively. Six classes of LULC were identified:

156 agricultural land, bare land, wetland, water, wetland vegetation, and built-up area (Table 1).

157 Table1. Description classes by maximum likelihood algorithm classification.

\begin{tabular}{|l|l|}
\hline Land cover types & Description \\
\hline Agricultural Land & $\begin{array}{l}\text { High land agriculture, Cropland, Fallow land, Land under seasonal } \\
\text { cultivation, Land covered with grass but is very well managed by } \\
\text { grazing of domestic animals }\end{array}$ \\
\hline Bare Land & Barren rocky/stony, Mountain, Barren hill, Salt affected land \\
\hline Wetland & $\begin{array}{l}\text { River, permanent open water, perennial lakes and reservoirs, Water bodies, } \\
\text { Areas covered by water }\end{array}$ \\
\hline Wetland Vegetation & Wetlands areas with extensive permanent reed vegetation, Land with marshy \\
vegetation,
\end{tabular}

$159 \quad 2.5$ Estimating the accuracy of the classified land-cover maps

160 The accuracy of the classified image was evaluated using data not used for classification. The 161 accuracy was assessed with an error matrix and by calculating overall accuracy and Kappa 162 coefficients. The overall accuracy was calculated as the sum of elements of the main diagonal line 163 of the error matrix (Equation 1): 


$$
O A=\frac{1}{n} \sum_{i=1}^{n} P i i
$$

164 Where OA is overall accuracy, $\mathrm{n}$ is the number of experimental pixels, and $\Sigma$ Pii is the sum of

165 elements of the main diagonal of the error matrix.

The Kappa coefficient regards incorrectly classified pixels and calculates the classification accuracy compared to a wholly random classification (Mitsova et al., 2011). The Kappa coefficient was calculated according to Equation 2:

$$
\text { Kappa }=\frac{P_{0}-P_{c}}{1-P_{c}} \times 100
$$

Where $\mathrm{P}_{0}$ is observed, accuracy and $\mathrm{P}_{c}$ is expected agreement.

\subsection{Evaluating soil erosion}

The RUSLE model was used to estimate the average annual soil erosion. This model contains six parameters: soil erodibility $(\mathrm{K})$, rainfall erosivity $(\mathrm{R})$, vegetation cover $(\mathrm{C})$, the length $(\mathrm{L})$ and steepness (S) of slopes, and conservation practices $(\mathrm{P})$ in place. Sensitivity to erosion depends on soil characteristics. Changes in soil characteristics are related to LULC and topography (Pradhan et al., 2012). Soil erosion is calculated using Equation 3 (Wischmeier and Smith, 1978):

$$
\mathrm{A}=\mathrm{R} \times \mathrm{K} \times \mathrm{LS} \times \mathrm{C} \times \mathrm{P}
$$

Where $\mathrm{A}$ is average soil erosion $\left(\mathrm{Mg} \mathrm{ha}^{-1} \mathrm{y}^{-1}\right), \mathrm{R}$ is rainfall erosivity ( $\left.\mathrm{MJ} \mathrm{mm} \mathrm{ha}^{-1} \mathrm{y}^{-1} \mathrm{~h}^{-1}\right), \mathrm{K}$ is soil erodibility ( $\left.\mathrm{Mg} \mathrm{h} \mathrm{MJ}^{-1} \mathrm{~mm}^{-1}\right)$, LS is the topographic parameter, $\mathrm{C}$ is vegetation cover, $\mathrm{P}$ is the set of conservation practices in use. Each of these measures is detailed below.

\subsubsection{Rainfall erosivity $(R)$}

The rainfall erosivity factor was proposed by Wischmier and Smith to include the effects of weather on soil erosion and is defined as the potential for rainfall to cause erosion. It depends upon the physical properties of raindrops and is associated with direct energy in impact, kinetic energy of raindrops, and maximum 30-minute rainfall intensity (Wischmeier and Smith, 1978). The number of meteorological stations equipped with rain gauges are few in the study area. So, annual and monthly rainfall-based indices like the Fornier Index (an indicator of rainfall "aggressiveness") were used in the USLE and RUSLE models (Ferro et al., 1991; Renard and Freimund, 1994). A modified Fornier Index was calculated for all stations using equation 4. Inserting this index into 
190 Equations 5 and 6 is a way to calculate $\mathrm{R}$ for areas without detailed rainfall data (Renard and 191 Freimund, 1994). The R was estimated for weather stations in the study area at Ahvaz, Abadan, 192 Ramhormoz, Omidyeh (Aghajari), Omidyeh (Payegah), and Mahshahr. The IDW ${ }^{1}$ model was used 193 to generalize point rainfall data to the whole study area:

$$
M F I=\frac{\sum_{I=1}^{12} P i^{2}}{P}
$$

194 Where $\mathrm{Pi}$ is the average monthly precipitation $(\mathrm{mm})$ in a month $\mathrm{i}$ and $\mathrm{P}$ is average annual 195 precipitation $(\mathrm{mm})$.

$$
\begin{array}{cr}
R=0.07397 \times M F I^{1.847} & M F I<55 m \\
R=\left(95.77-6.081 \times F+0.4770 \times M F I^{2}\right) & M F I \geq 55 m m
\end{array}
$$

\subsubsection{Soil erodibility $(K)$}

199 Soil erodibility indicates the inherent sensitivity of soil to erosion and the ease of dispersion of soil 200 particles due to raindrops' kinetic energies and transportation of particles by runoff force. In this 201 study, soil erodibility was estimated using soil texture data and the percentage of organic matter in 202 the soils (Table 2).

Table 2. Determining the erodibility factor using texture and organic matter content for soils in the study area

\subsubsection{Topographic factor (LS)}

208 Slope (S in \%) and its length ( $\mathrm{L}$ in $\mathrm{m}$ ) influence erosion. Multiplying these two factors determines 209 the topographic factor (LS) (Ayoubi et al., 2007). A 30-m digital elevation model (DEM) was 
211 flow accumulation and slope. These maps were extracted from the DEM. LS was determined by 212 Equation 7 (Foster and Wischmeier, 1974; Moore and BuRCH, 1986):

$$
\mathrm{LS}=\left[(\text { Flow Accumulation grid }) \times \frac{\text { Cell Size }}{22.13}\right]^{0.4} \times\left[\frac{\operatorname{Sin}(\text { Slope grid } \times 0.01745)}{0.0896}\right]^{1.3}
$$

213 Flow Accumulation is the accumulation of upslope flows for each cell. Cell size is the network cell 214 size $(30 \mathrm{~m})$. And slope was derived from the DEM. The constant 0.01745 was used to convert slope measures from degrees to radians in GIS.

216

\subsubsection{Vegetation-cover factor $(C)$}

$218 \mathrm{C}$ is the loss ratio of soil from one region with a specific vegetation cover to a plot in tilled farmland without plant residue (Wischmeier and Smith, 1978). C was calculated with equation 8 (Lin et al., 220 2002).

$$
\mathrm{C}=(-\mathrm{NDVI}+1) / 2
$$

Where $\mathrm{C}$ is the vegetation cover factor, and NDVI is the normalized difference vegetation index, 222 calculated by equation 9.

$$
N D V I=\frac{N I R-R E D}{\text { NIR }+ \text { RED }}
$$

223

Where NIR and RED are the reflectance values of a location in the near-infrared and red bands, this index ranges from -1 to +1 . For dense vegetation, it approaches to +1 . It approaches -1 for surfaces covered by water or snow or landscapes obscured by clouds.

\subsubsection{Protection support practice $(\mathbf{P})$}

$\mathrm{P}$ is the loss ratio of soil by using a specific tillage practice that may promote or battle erosion. Straight-row cultivation is the worst approach, particularly if oriented downslope. Conservation practices include contouring, strip farming, or terracing. $\mathrm{P}$ is lower as conservation practices are increasingly effective at preventing soil erosion, and less soil loss occurs (Wischmeier and Smith, 1978). The values of the $\mathrm{P}$ factor were determined by reclassifying land cover based on Table 3 . As there were no conservation practices in use in the study area, $\mathrm{P}$ was determined by land cover classes. 
Table 3. Values of $P$ factor for LULC classes in the study area

\begin{tabular}{|c|c|c|c|c|c|c|}
\hline LULC & $\begin{array}{c}\text { Agriculture } \\
\text { land }\end{array}$ & Wetland & $\begin{array}{c}\text { Built-up } \\
\text { area }\end{array}$ & Bare land & Water & $\begin{array}{c}\text { Wetland } \\
\text { vegetation }\end{array}$ \\
\hline P factor value & 0.4 & 1 & 1 & 1 & 1 & 0.12 \\
\hline
\end{tabular}

\subsection{The impact of LULC changes on soil erosion}

240 To determine the effect of LULC change on soil erosion, a map of land cover for each year as 241 compared to the map of soil erosion during the same year. Using the natural breaks (Jenks) 242 classification method, the soil erosion intensity map was categorized into five soil erosion classes, 243 i.e., very low $(<0.5)$, low (0.51-1), medium (5-15), high (2.1-5) and very high $(>5)$. The erosion 244 rates and classes of erosion (Table 4) were determined for each land cover class.

Table 4. The value of different classes of soil erosion

\begin{tabular}{|c|c|c|c|c|c|}
\hline Class & very low & Low & medium & high & very high \\
\hline Erosion Rate & $<0.5$ & $0.51-1$ & $1.1-2$ & $2.1-5$ & $>5$ \\
\hline
\end{tabular}

246 3. Results

\section{3.1. Evaluating classification accuracy}

248 The assessment of LULC class efficiencies (Table 5) reveals that the highest coefficients of overall accuracy and kappa were $93 \%$ and 0.91 for the classification for 2017 and the lowest were $88 \%$ 250 and 0.86 for 1989.

Table 5. Evaluation of the accuracy of LULC classes

\begin{tabular}{|c|c|c|c|c|c|c|}
\hline \multirow{2}{*}{ LULC } & \multicolumn{2}{|c|}{1989} & \multicolumn{2}{c|}{2003} & \multicolumn{2}{c|}{2017} \\
\cline { 2 - 7 } & $\begin{array}{c}\text { Users } \\
\text { accuracy }\end{array}$ & $\begin{array}{c}\text { Producers } \\
\text { accuracy }\end{array}$ & $\begin{array}{c}\text { Users } \\
\text { accuracy }\end{array}$ & $\begin{array}{c}\text { Producers } \\
\text { accuracy }\end{array}$ & $\begin{array}{c}\text { Users } \\
\text { accuracy }\end{array}$ & $\begin{array}{c}\text { Producers } \\
\text { accuracy }\end{array}$ \\
\hline Built-up areas & 100 & 90 & 80 & 100 & 80 & 66 \\
\hline Wetland vegetation & 100 & 85 & 100 & 100 & 85 & 100 \\
\hline Wetland & 88 & 66 & 90 & 90 & 88 & 100 \\
\hline Bare land & 82 & 100 & 96 & 89 & 95 & 95 \\
\hline Agricultural land & 82 & 100 & 88 & 93 & 100 & 90 \\
\hline Water & 100 & 83 & 100 & 91 & 100 & 100 \\
\hline Overall accuracy (\%) & \multicolumn{3}{|c|}{88} & \multicolumn{2}{|c|}{92} & \multicolumn{2}{c|}{93} \\
\hline kappa coefficient & \multicolumn{2}{|c|}{0.86} & \multicolumn{2}{|c|}{00} \\
\hline
\end{tabular}




\subsection{Land use/cover change}

256 The LULC maps for 1989, 2003, and 2017 were categorized into six classes: bare land, wetland, 257 built-up areas, water, wetland vegetation, and agricultural land (Figure 2). from 1989 to 2003, the 258 areas of agricultural land, wetland, water, and built-up areas have increased by $8.12 \%, 3.36 \%$, $2595.6 \%$, and $0.08 \%$ respectively (Figure 3), but bare land has decreased by $12.63 \%$, and wetland 260 vegetation has decreased by $4.53 \%$ over this period. From 2003 to 2017, $16.3 \%$ and $0.28 \%$ 261 increases have happened in bare land and built-up area, respectively. But, over this period, 262 agricultural land has shrunk by $7.04 \%$, wetland by $2.87 \%$, water by $2.92 \%$, and wetland vegetation 263 by $3.7 \%$.

264

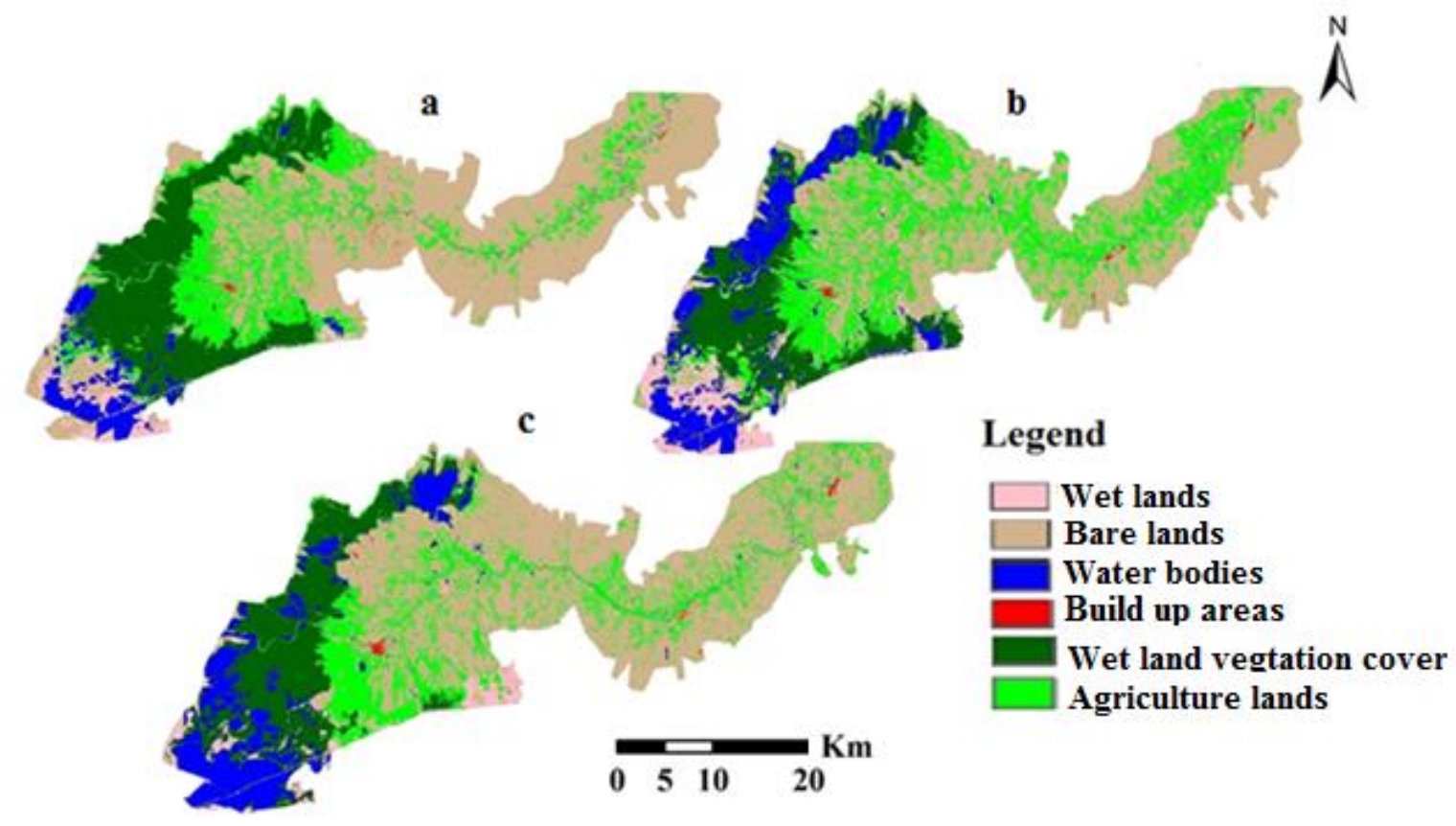




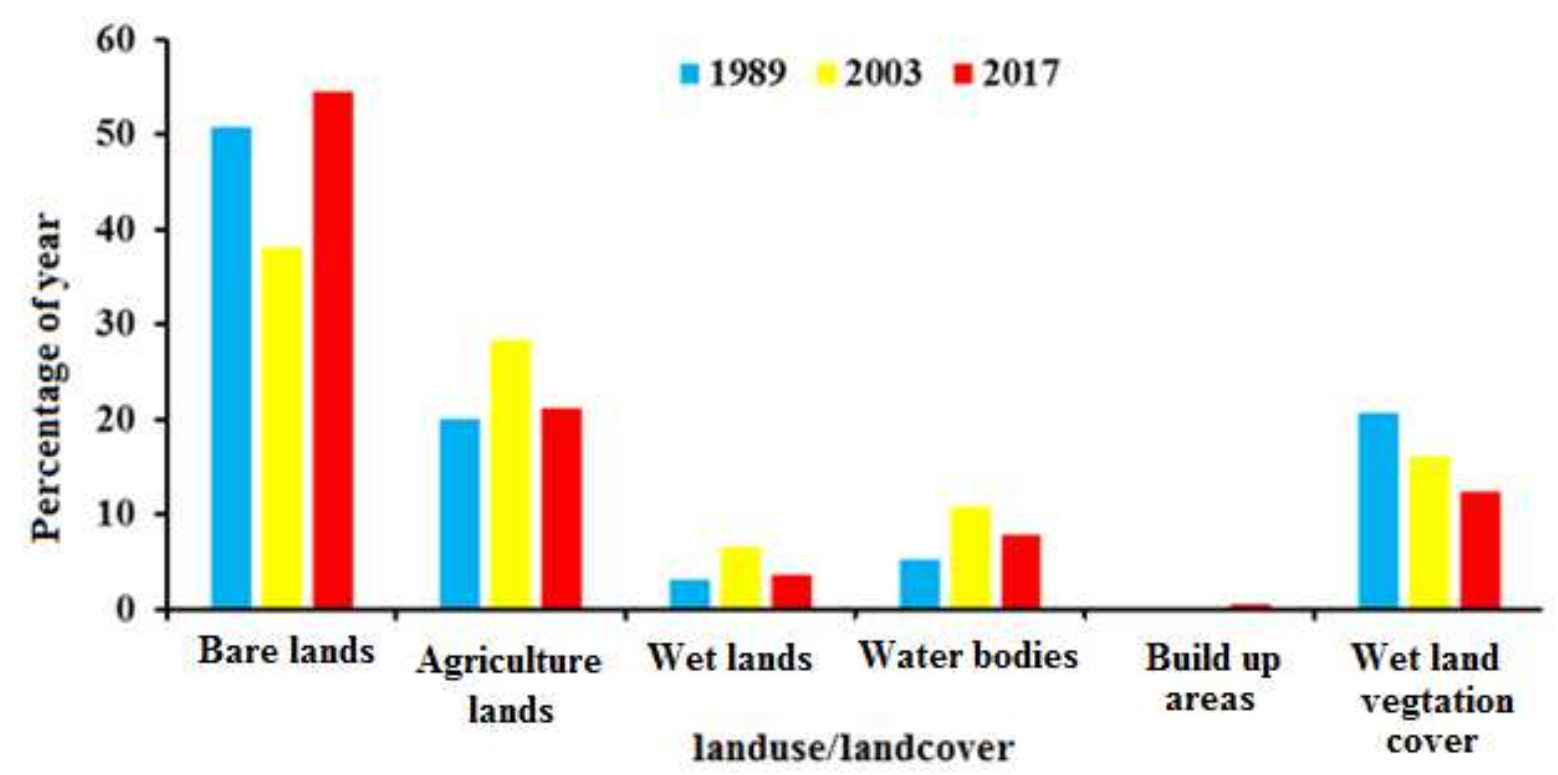

\subsection{Rainfall erosivity factor}

$273 \mathrm{R}$ was calculated for the six weather stations (Table 6). Due to a low RMSE, IDW interpolation 274 was used to map the values over the period 1988 to 2014 (Figure 4a). R ranged from 26 to 82 across 275 the study area.

Table 6. Estimated R (MJ mm ha $\left.{ }^{-1} y^{-1} h^{-1}\right)$ for weather stations in the study area

\begin{tabular}{|c|c|c|c|c|c|}
\hline Synoptic station & MFI & $\mathrm{R}$ & Synoptic station & MFI & $\mathrm{R}$ \\
\hline Ahwaz & 37.85 & 120.34 & Ramhormoz & 54.79 & 60.79 \\
\hline Abadan & 22.76 & 22.76 & Omidyeh (Aghajari) & 44.5 & 81.95 \\
\hline Mahshahr & 35.43 & 53.81 & Omidyeh (Payegah) & 43.77 & 79.51 \\
\hline
\end{tabular}

$280 \mathrm{~K}$ was estimated using the conditions described above (Table 2). The values range from 0.14 to 281 0.34. K was mapped (Figure 4b). 
LS was mapped using the digital elevation model and Equation 7, considering the interaction between flow accumulation and topography (Figure 4c). LS ranges from 0 to 41 in the study region.

\subsection{Vegetation cover factor}

$\mathrm{C}$ was determined by combining the NDVI with Equation 8. The factor is inversely correlated to

NDVI. C was mapped for 1989, 2003, and 2017 (Figures 4d, 4e, 4f). C ranged from 0.17 to 0.67 for $1989,0.13$ to 0.75 for 2003 , and 0.29 to 0.58 for 2017 . The map reveals that the highest and lowest values occurred in non-vegetated and densely vegetated areas, respectively.

\subsection{Protection support practice factor}

The maps of $\mathrm{P}$ for each of the study years were created by reclassifying land cover classes and 295 assigning the corresponding numbers from Table 3 (Figures $4 \mathrm{~g}, 4 \mathrm{~h}, 4 \mathrm{i}$ ). This factor ranged from 0.1 to 1 for all three years.
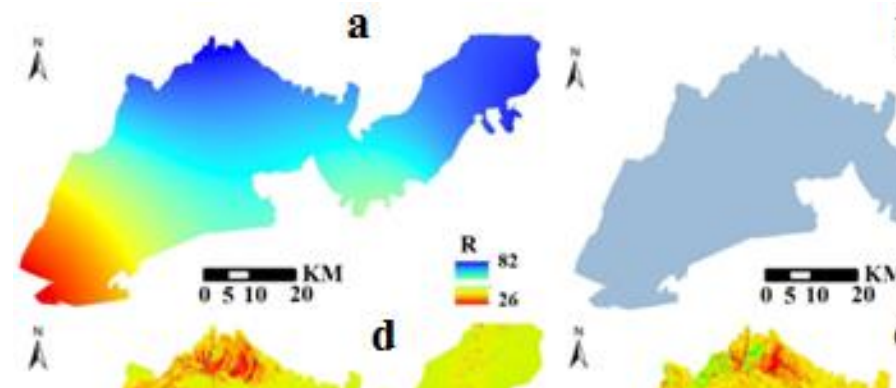

$\hat{A}$
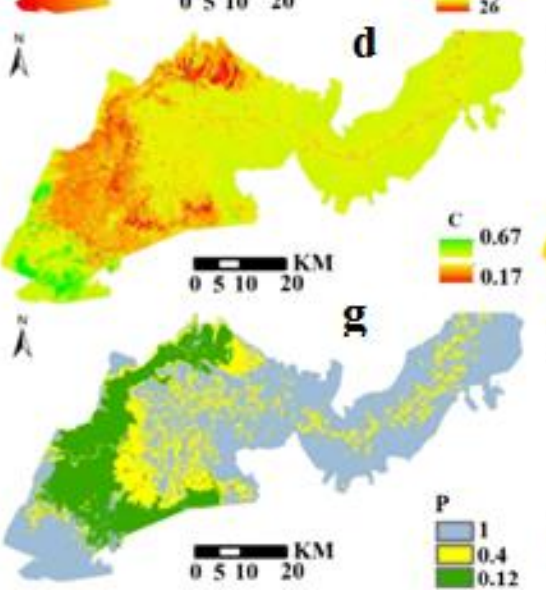

Figure 4. Maps of a) rainfall erosivity factor, b) soil erodibility factor, c) topographic factor, d) vegetation cover factor for $\mathbf{1 9 8 9}$, e) vegetation cover factor for $\mathbf{2 0 0 3}$, f) vegetation cover factor for 2017, g) conservation support practice factor for 1989, h) conservation support practice factor for 2003, and i) conservation support practice factor for 2017. 


\subsection{Annual soil erosion}

The five factors were layered in ArcGIS, combining operators to determine annual soil erosion rates and yearly soil loss. The values of soil loss were grouped into five "risk" classes, and the classes were mapped for 1989, 2003, and 2017 (Figures 5).

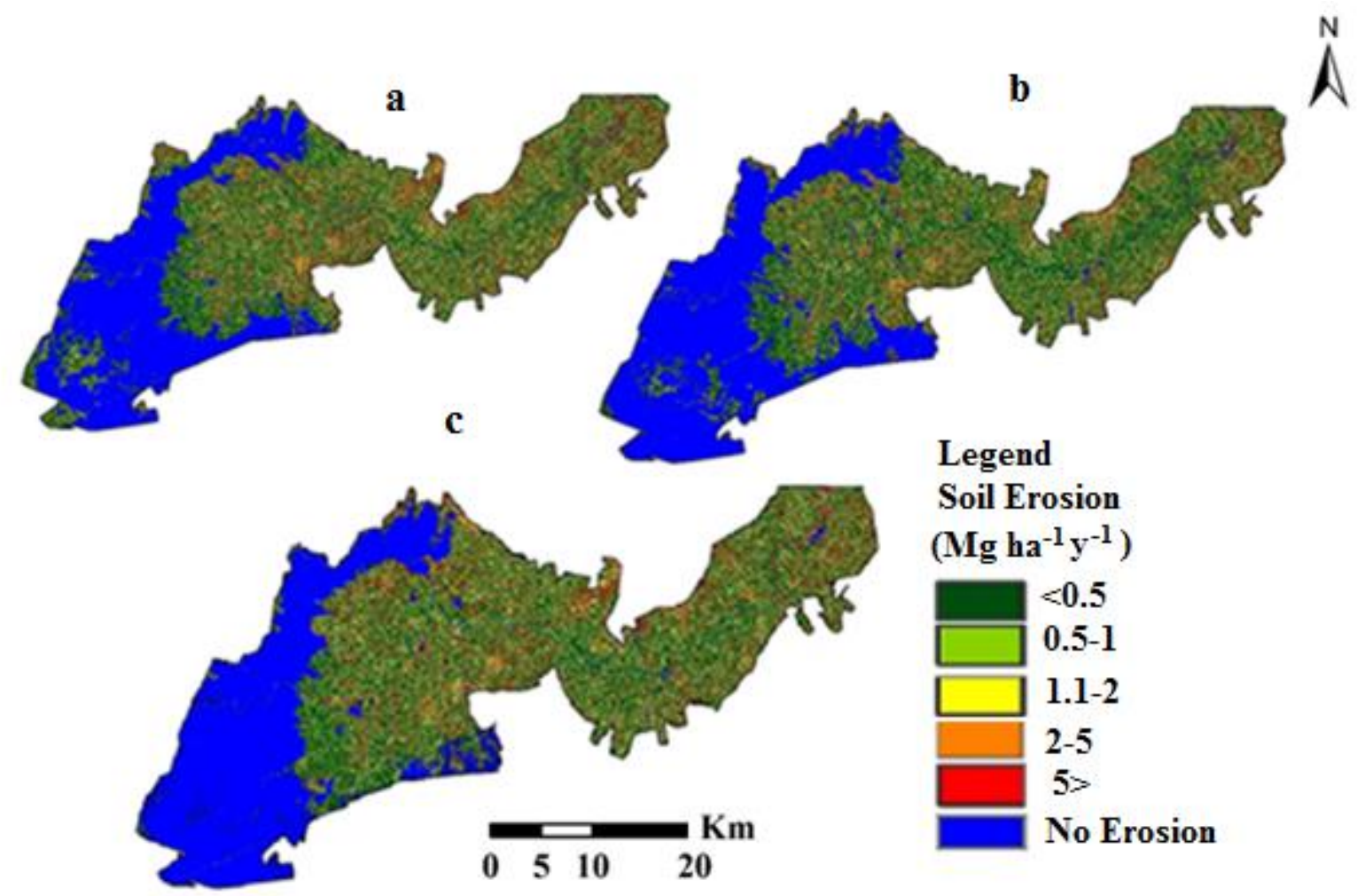

308

309

310

Figure 5. Soil erosion map for 1989 (a), 2003(b), and 2017(c)

The total area of each soil erosion class was determined (Figure 6). The trends of the soil erosion classes are variable, some decreasing from 1989 to 2003 and then increasing from 2003 to 2017 and some vice versa. During the first period (1989 to 2003), regions of very low $(<0.5)$ and low ( 0.5 to 1.0$)$ rates of erosion increased in the area, while the regions of moderate (1.1 to 2.0$)$, high (2.0 to 5.0) and very high (>5.0) rates decreased in spatial extent. During the second period, the reverse occurred. Areas classified as having very low and low erosion rates decreased by $3.7 \%$ and $0.4 \%$, respectively, while areas classified as moderate, high, and very high increased by $1.2 \%$, $1.8 \%$, and $1.1 \%$, respectively. 

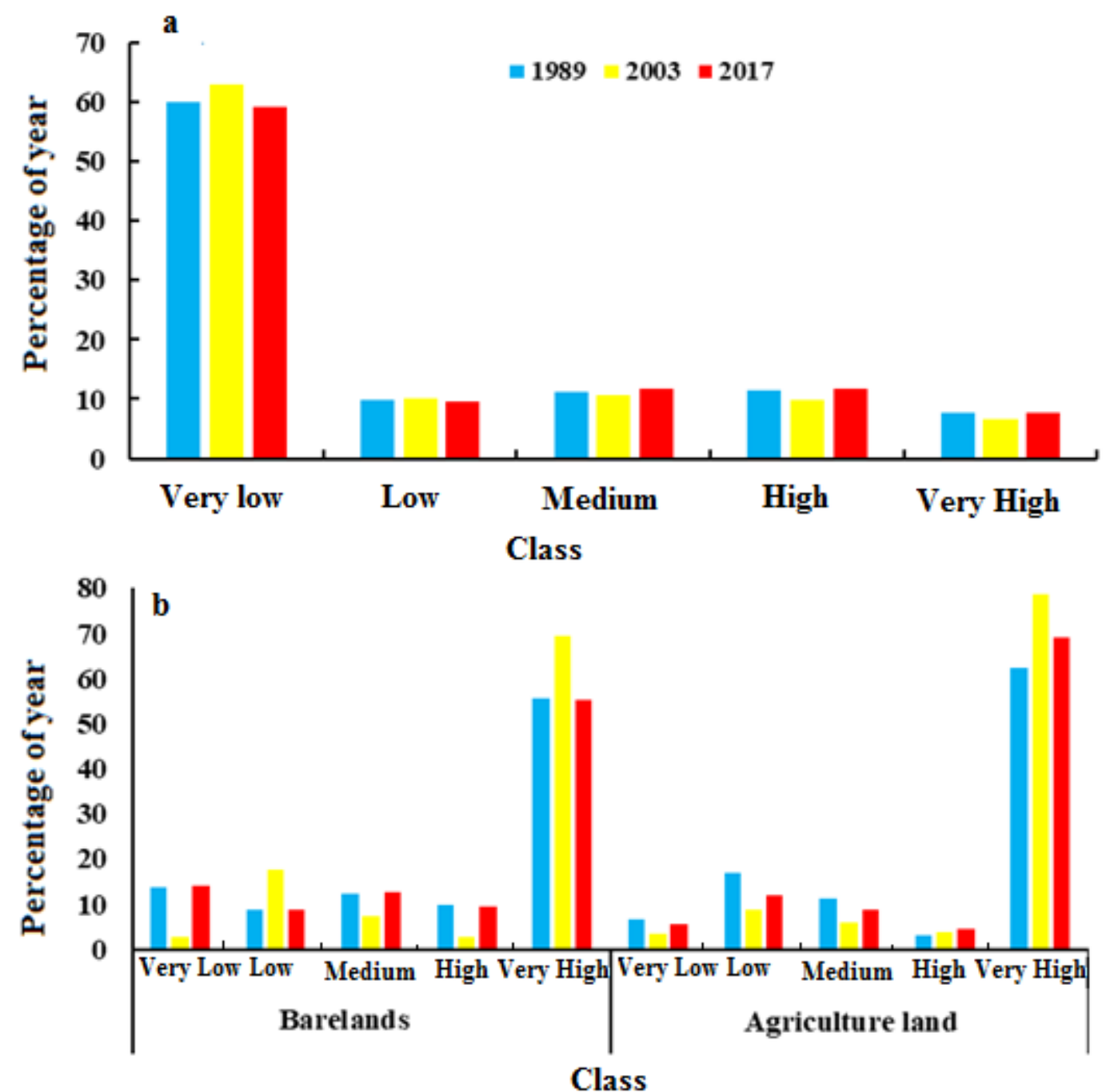

Class

319 Figure 6. The percentages of the area classified into each soil erosion class (a) and erosion classes for 320 bare land and agricultural land (b).

\subsection{Effects of land cover changes on soil erosion trends}

323 Soil erosion occurred only on agricultural lands and bare lands. It had not occurred on wetlands, in

324 built-up areas, or in areas of wetland vegetation (and erosion was certainly not apparent on water 325 features). The erosion rates on bare lands dropped in the very low, medium, and high erosion areas 326 from 1989 to 2003 (Figure 6b), while areas classified as low and high erosion increased in size by $3278.93 \%$ and $14.03 \%$, respectively. The areas of bare land classified as very low, medium, and high 328 erosion increased from 2003 to 2017, and the areas classified as low and high decreased by $9.03 \%$ 329 and $14.19 \%$. 
330 Erosion on agricultural lands changed patterns in 1989, 2003, and 2017 as well. Over the period 331 from 1989 to 2003, lands classified as very low, low, and moderate erosion decreased by 3.25\%, $3328.38 \%$, and $5.49 \%$, respectively. The spread of high and very high erosion increased by $0.88 \%$ and $33316.19 \%$ during this period. Between 2003 and 2017, areas of very low, low, moderate, and high 334 erosion increased $2.07 \%, 3.45 \%, 3.04 \%$, and $0.75 \%$, respectively, but areas of very high erosion increased by $9.32 \%$ (Figure 6b). From 1989 to 2017, the total area classified (for all LULCs) as having very low and low ( $<1$ ton per hectare) soil-erosion diminished in amount, whereas the total area of the classes $>1 \mathrm{Mg} \mathrm{ha}^{-1} \mathrm{y}^{-1}$ increased. It can be concluded that soil erosion was worsening in the study area overall.

\section{Discussion}

341 Soil erosion and sediment transportations are natural processes that have been accelerated using 342 forest fires (Di Prima et al., 2018), grazing (Antoneli et al., 2018), agriculture (Rodrigo-Comino et 343 al., 2018), and road and railway construction (Hazbavi et al., 2018). Models are vital tools to discern soil erosion processes, and they inform us about the temporal and spatial changes that are taking place within regions. Soil erosion is also a significant driver of land degradation globally, but also throughout Iran (Ahmadi, 2006; Rahman et al., 2009). This study investigated the impacts of LULC changes on soil erosion. In This study, overall classification accuracy and kappa coefficient for these 28 years, is more than $88 \%$ and 0.86 , respectively, showing the high accuracy Maximum likelihood algorithm of land use change determination (Lu et al., 2019, Eskandari 350 Damaneh et al., 2020). Based on the results, we observe that an assessment of LULC changes from 1989 to 2003 revealed diminishing bare land and wetland vegetation with increases of agricultural land and water features. The areas of agricultural lands and wetlands decreased from 2003 to 2017, 353 while bare lands increased in the area.

354 Consequently, the areas with soil erosion rates $<1 \mathrm{Mg} \mathrm{ha}^{-1} \mathrm{y}^{-1}$ have diminished, and areas having rates $>1 \mathrm{Mg} \mathrm{ha}^{-1} \mathrm{y}^{-1}$ increased in extent. The changes are a consequence of land abandonment, 356 which contributes to increasing vegetation cover and reduction of soil erosion and runoff yields 357 (Comino et al., 2017). Studies carried out in eastern Spain under specific climatic conditions (300 and $500 \mathrm{~mm}$ of precipitation $\mathrm{y}^{-1}$ ) showed that semi-arid Mediterranean landscapes would respond 359 to abandonment with low vegetation recovery rates and high erosion rates. In contrast, wet 360 Mediterranean vegetation recovers more quickly after abandonment, and erosion rates remain low 
(Rodrigo Comino et al., 2018). Vegetation is the key factor controlling soil erosion. It has been

362 shown in many ecosystems, but primarily in semi-arid landscapes and in agriculture systems where water and sediment delivery are very active due to high connectivity (Cerdà et al., 2018a). Changes in LULC have increased soil erosion in the study area. The region has been affected by drought, improper water management in upstream watersheds, dam construction, inter-basin water transfers, and lack of assigned water rights to downstream lands. The LULC changes are, however, the ones that immediately increase erosion and can trigger desertification. It has been shown by previous research in other regions of the world. Also studying the effects of land use change on erosion trends, a similar study undertaken in the Yezat Basin of northwestern Ethiopia showed that vegetation cover decreased $91 \%$ between 2001 and 2010 and then increased $88 \%$ between 2010 and 2015 due to the implementation of a comprehensive water management program (Tadesse et al., 2017).

Accelerated erosion destroys agricultural soils, degrades productivity of the soils, and contaminates water bodies with sedimentation. In this study, Landsat imagery was used to assess LULC change and to model RUSLE to calculate soil erosion. Soil erosion seems to be an inevitable and natural occurrence, but soil erosion should not exceed acceptable levels. Soil erosion is usually deemed acceptable when it does not exceed the rate of soil formation. This principle is a feature of the

378 United Nations Goals for Sustainability (reviewed by Keesstra et al., 2016).

Based on the information available and taking all factors into account, the mean rate of soil formation in the study area is approximately $1 \mathrm{Mg} \mathrm{ha}^{-1} \mathrm{y}^{-1}$. Regarding this as the average rate, approximately $24.94 \%, 24.65 \%$, and $27.11 \%$ of the area experienced unacceptable levels of soil erosion in 1989, 2003, and 2017, respectively. According to the results, the areal extent of soil erosion $>1 \mathrm{Mg} \mathrm{ha}^{-1} \mathrm{y}^{-1}$ has been increased by about $46.2 \%$ between 2003 and 2017. These changes can be explained by climatic factors and short-term weather phenomena (like drought), anthropogenic disruption of natural systems, and improper management. Climate factors are usually natural phenomena that occur over time, but because they reduce vegetation cover, droughts also reduce rainfall erosivity. Disruptions include dam construction, inter-basin water transfers, and land use changes. The impacts of human activities can be minimized with proper management, consideration of environmental issues, proper allocation of water rights, comprehensive conservation planning, and sustainable development. This study highlights the need 
391 to address this issue by presenting solutions that support management and the goals of 392 conservation.

393 One of the main issues clarified by this study is that LU/LC changes are key to explain sediment 394 deposition in a catchment, and these changes could lead to land degradation due to exceeding 395 sustainable rates of soil losses. Erosion must be controlled over the next decade to maintain soil 396 quality and to prevent land degradation. New policies are necessary. A new policy that could be 397 supported is one that improve plant vegetation in the fields under production and on the bare lands. 398 Bare lands should be covered with straw to decrease water and soil losses and to increase growth 399 of vegetative. On agricultural land, the government should encourage using the catch crops, 400 mulches, weeds, pruned and chipped branches or even geotextiles such as those used in modern 401 studies around the world. Kirchhoff et al. (2017) found that organic farming contributes to soil and 402 plant may recovery and controls soil erosion. Cerdà et al. (2018b) demonstrated that soil erosion 403 could be reduced if the citrus plantations ground is covered with chipped or pruned branches on 404 the soil surface. In addition, Cerdà et al. (2018a) used similar approaches using catch crops and 405 weeds in the Canyoles River watershed in Spain.

\section{Conclusions}

409 Changing LULCs were determined to be soil erosion processes and rates due to the soil and 410 vegetation properties connected to specific land uses. Maps of LULCs were created by applying 411 supervised classification and maximum likelihood methods using pre-processing of TM, ETM, and 412 OLI images from 1989, 2003, and 2017. One of the advantages of the RUSLE model is that it is used 413 to calculate erosion in areas of the world that do not have sufficient and comprehensive data. With 414 the development and advancement of remote sensing science and GIS, up-to-date and complete 415 data are provided to calculate erosion. In this study, erosion was estimated under the estimated user 416 change of satellite imagery between 1989, 2003 and 2017. The results showed that the erosion 417 occurrence has increased >1 Mg ha ${ }^{-1} \mathrm{y}^{-1}$ between 1989 and 2017, which was due to the increase in 418 barren and agricultural lands. Based on the average erosion rate, approximately 24.94\%, 24.65\%, 419 and $27.11 \%$ of the area have experienced unacceptable levels of soil erosion in 1989, 2003, and 4202017 , respectively. According to the results, the areal extent of soil erosion $>1 \mathrm{Mg} \mathrm{ha}^{-1} \mathrm{y}^{-1}$ has been increased by about $46.2 \%$ between 2003 and 2017. LU/LC changes have increased soil erosion in 
Shadegan International Wetland. This study highlights the need to plan and management the LU/LC changes to achieve sustainable development. We recommend that nature-based solutions should be applied throughout the study region to reduce the soil losses.

\section{References}

Ahmadi, H., 2006. Applied Geomorphology: water erotion. Fifthe ed. University of Tehran Press. Antoneli, V., Rebinski, E. A., Bednarz, J. A., Rodrigo-Comino, J., Keesstra, S. D., Cerdà, A., Pulido Fernández , M., 2018. Soil Erosion Induced by the Introduction of New Pasture Species in a Faxinal Farm of Southern Brazil. Geosci. Can. 8(5), 166-178.

Ayoubi, Sh., Khormali, F., Shataee, Sh., 2007. Optimal resolution investigation of digital elevation models by geostatistical technique to compute topographic factor (LS) for RUSLE equation in Talesholia district, Golestan province. Pajouhesh \& Sazandegi. 77, 122-129.

Bini, C., Gemignani, S., Zilocchi, L., 2006. Effect of different landuse on soil erosion in the prealpine fringe (North-East Italy): Ion budget and sediment yield. Sci. Total. Environ. 369(1), 433440.

Brath, A., Castellarin, A., Montanari, A., 2002. Assessing the effects of land-use changes on annual average gross erosion. Hydrol. Earth. Syst. Sc. 6(2), 255-265.

Cerdà, A., Rodrigo-Comino, J., Giménez-Morera, A., Keesstra, S. D., 2018a. Hydrological and erosional impact and farmer's perception on catch crops and weeds in citrus organic farming in Canyoles river watershed, Eastern Spain. Agric. Ecosyst. Environ. 258, 49-58.

Cerdà, A., Rodrigo-Comino, J., Giménez-Morera, A., Novara, A., Pulido, M., Kapović-Solomun, M., Keesstra, S. D., 2018b. Policies can help to apply successful strategies to control soil and water losses. The case of chipped pruned branches (CPB) in Mediterranean citrus plantations. Land Use Policy. 75, 734-745.

Chen, X., 2008. Landuse/cover change in arid areas in China. Beijing: Science Press.

Clark, W. C., Dickson, N. M., 2003. Sustainability science: the emerging research program. Proc. Natl. Acad. Sci. 14, 8059-8061.

Comino, J. R., Bogunovic, I., Mohajerani, H., Pereira, P., Cerdà, A., Ruiz Sinoga, J. D., Ries, J. B., 2017. The impact of vineyard abandonment on soil properties and hydrological processes. Vadose Zone J. 16(12), 1-14.

Daliakopoulos, I. N., Pappa, P., Grillakis, M. G., Varouchakis, E. A., Tsanis, I. K., 2016. Modeling Soil Salinity in Greenhouse Cultivations Under a Changing Climate With SALTMED: Model Modification and Application in Timpaki, Crete. J. Soil Sci. 181(6), 241-251.

De Wit, M., Behrendt, H., 1999. Nitrogen and phosphorus emissions from soil to surface water in the Rhine and Elbe basins. Water Sci. Technol. 39(12), 109-116.

Di Prima, S., Lassabatere, L., Rodrigo-Comino, J., Marrosu, R., Pulido, M., Angulo-Jaramillo, R., Pirastru, M., 2018. Comparing transient and steady-state analysis of single-ring infiltrometer data for an abandoned field affected by fire in Eastern Spain. Water. 10(4), 514-531.

Dominey-Howes, D., 2018. Hazards and disasters in the Anthropocene: some critical reflections for the future, Geoscience Letters. 5(1), 7-22.

Eskandari, H., Borji, M., Khosravi, H., Mesbahzadeh, T., 2016. Desertification of forest, range and desert in Tehran province, affected by climate change. solid Earth. 7(3), 905-915. 
Farhan, Y., Nawaiseh, S., 2015. Spatial assessment of soil erosion risk using RUSLE and GIS techniques. Environ. Earth Sci. 74(6), 4649-4669.

Ferro, V., Giordano, G., Iovino, M., 1991. Isoerosivity and erosion risk map for Sicily. Hydrolog. Sci. J. 36(6), 549-564.

Foster, G., Wischmeier, W., 1974. Evaluating irregular slopes for soil loss prediction. T Asabe. 17(2), 305-309.

Griggs, D., Stafford-Smith, M., Gaffney, O., Rockström, J., Öhman, M. C., Shyamsundar, P., Noble, I., 2013. Policy: Sustainable development goals for people and planet. Nature. 495(7441), 305.

Guan, D., Li, H., Inohae, T., Su, W., Nagaie, T., Hokao, K., 2011. Modeling urban landuse change by the integration of cellular automaton and Markov model. Ecol. Model. 222(20), 3761-3772.

Gumel, I. A., Aplin, P., Marston, C. G., \& Morley, J. (2020). Time-series satellite imagery demonstrates the progressive failure of a city master plan to control urbanization in Abuja, Nigeria. Remote Sensing, 12(7), 1112.

Hazbavi, Z., Keesstra, S. D., Nunes, J. P., Baartman, J. E., Gholamalifard, M., Sadeghi, S. H., 2018. Health comparative comprehensive assessment of watersheds with different climates. Ecol. Indic. 93, 781-790.

Hegazy, I. R., \& Kaloop, M. R. (2015). Monitoring urban growth and land use change detection with GIS and remote sensing techniques in Daqahlia governorate Egypt. International Journal of Sustainable Built Environment, 4(1), 117-124.

Houben, P., Hoffmann, T., Zimmermann, A., Dikau, R., 2006. Landuse and climatic impacts on the Rhine system (RheinLUCIFS): Quantifying sediment fluxes and human impact with available data. Catena. 66(1), 42-52.

Issaka, S., Ashraf, M. A., 2017. Impact of soil erosion and degradation on water quality: a review. Geology, Landsc. Ecol. 1(1), 1-11.

Keesstra, S. D., Bouma, J., Wallinga, J., Tittonell, P., Smith, P., Cerdà, A., Bardgett, R. D., 2016. The significance of soils and soil science towards realization of the United Nations Sustainable Development Goals. Soil. 2(2), 111-128.

Keesstra, S. D., Temme, A. J. A. M., Schoorl, J. M., Visser, S. M., 2014. Evaluating the hydrological component of the new catchment-scale sediment delivery model LAPSUSD. Geomorphology. 212, 97-107.

Keesstra, S., Mol, G., de Leeuw, J., Okx, J., de Cleen, M., Visser, S., 2018. Soil-related sustainable development goals: Four concepts to make land degradation neutrality and restoration work. Land, 7(4), 1-20.

Khosravi, H., Azareh, A., Dameneh, H. E., Sardoii, E. R., Dameneh, H. E., 2017. Assessing the effects of the climate change on land cover changes in different time periods. Arab. J. Geosci. 10(4), 93-94.

Kirchhoff, M., Rodrigo-Comino, J., Seeger, M., Ries, J. B., 2017. Soil erosion in sloping vineyards under conventional and organic land use managements (Saar-Mosel valley, Germany). Geophys. Res. Lett. 43(1), 119-140.

Lambin, E. F, 1997. Modelling and monitoring land-cover change processes in tropical regions. Prog. Phys. Geog. 21(3), 375-393.

Lin, C.-Y., Lin, W.-T., Chou, W.-C., 2002. Soil erosion prediction and sediment yield estimation: the Taiwan experience. Soil Till Res. 68(2), 143-152.

Mitsova, D., Shuster, W., Wang, X., 2011. A cellular automata model of land cover change to integrate urban growth with open space conservation. Landsca. Urban Plan. 99(2), 141-153. 
Moore, I. D., Burch, G. J., 1986. Physical basis of the length-slope factor in the Universal Soil Loss Equation. Soil Sci. Soc. Am. J. 50(5), 1294-1298.

Mutua, B., Klik, A., Loiskandl, W., 2006. Modelling soil erosion and sediment yield at a catchment scale: the case of Masinga catchment, Kenya. Land Degrad. Dev. 17(5), 557-570.

Ozesmi, S. L., Bauer, M. E., 2002. Satellite remote sensing of wetlands. Wetl. Ecol. Manag.10(5), 381-402.

Pradhan, B., Chaudhari, A., Adinarayana, J., Buchroithner, M. F., 2012. Soil erosion assessment and its correlation with landslide events using remote sensing data and GIS: a case study at Penang Island, Malaysia. Environ. Monit. Assess. 184(2), 715-727.

Rahimi Blouchi, L., Zarkar, A., Malekmohammadi, B., 2013. Detecting environmental change of Shadegan international wetland using remote sensing and WRASTIC index (Case study: Shadegan international wetland). RS and GIS for Nat. Resour. 3(4), 43-55.

Rahman, M. R., Shi, Z., Chongfa, C., 2009. Soil erosion hazard evaluation-an integrated use of remote sensing, GIS and statistical approaches with biophysical parameters towards management strategies. Ecol. Model. 220(13), 1724-1734.

Rawat, J. S., \& Kumar, M. (2015). Monitoring land use/cover change using remote sensing and GIS techniques: A case study of Hawalbagh block, district Almora, Uttarakhand, India. The Egyptian Journal of Remote Sensing and Space Science, 18(1), 77-84.

Renard, K. G., Foster, G. R., Weesies, G., Mccool, D., Yoder, D., 1997. Predicting soil erosion by water: a guide to conservation planning with the Revised Universal Soil Loss Equation (RUSLE). US Department of Agriculture, Agricultural Research Service Washington.

Renard, K. G., Freimund, J. R., 1994. Using monthly precipitation data to estimate the R-factor in the revised USLE. J. Hydrol. 157(1), 287-306.

Richards, J. A., Jia, X., 1999. Remote sensing digital image analysis, An intoduction. Springer.

Rickson, R., 2014. Can control of soil erosion mitigate water pollution by sediments? Sci. Total Environ. 468,1187-1197.

Rodrigo-Comino, J., Martınez-Hernández, C., Iserloh, T., Cerda, A., 2018. Contrasted impact of land abandonment on soil erosion in Mediterranean agriculture fields. Pedosphere. 28, 89-100.

Sachs, J D., McArthur J. W., 2005. The millennium project: a plan for meeting the millennium development goals. The Lancet, 365.9456, 347-353.

Sharma, A., Tiwari, K. N., Bhadoria, P., 2011. Effect of landuse land cover change on soil erosion potential in an agricultural watershed. Environ. Monit. Assess. 173(1-4), 789-801.

Tadesse, L., Suryabhagavan, K., Sridhar, G., Legesse, G., 2017. Landuse and landcover changes and Soil erosion in Yezat Watershed, North Western Ethiopia. J. Soil Water Conserv. 5(2), 8594.

Turner, B. L., Lambin, E. F., Reenberg, A., 2007. The emergence of land change science for global environmental change and sustainability. Proc. Nat. Acad. Sci. 104(52), 20666-20671.

Verstraeten, G., Oost, K., Rompaey, A., Poesen, J., Govers, G., 2002. Evaluating an integrated approach to catchment management to reduce soil loss and sediment pollution through modelling. Soil Use Manage. 18(4), 386-394.

Wischmeier, W.H., Smith, D.D., 1978. Predicting rainfall erosion losses, Agriculture Handbook 537, U.S. Department of Agriculture Research Service, Washington DC, USA.

Xiao, J., Shen, Y., Ge, J., Tateishi, R., Tang, C., Liang, Y., \& Huang, Z. (2006). Evaluating urban expansion and land use change in Shijiazhuang, China, by using GIS and remote sensing. Landscape and urban planning, 75(1-2), 69-80 
Xiubin, H., Juren, J., 2000. The 1998 flood and soil erosion in Yangtze River. Water Policy. 1(6), 653-658.

Zare, M., Samani, A. N., Mohammady, M., Salmani, H., Bazrafshan, J., 2017. Investigating effects of landuse change scenarios on soil erosion using CLUE-s and RUSLE models. Int. J. Environ. Sci. Te. 14(9), 1905-1918.

Ranzi, R., Le, T. H., \& Rulli, M. C. (2012). A RUSLE approach to model suspended sediment load in the Lo river (Vietnam): Effects of reservoirs and land use changes. Journal of Hydrology, 422, 17-29.

Zare, M., Samani, A. N., Mohammady, M., Salmani, H., \& Bazrafshan, J. (2017). Investigating effects of land use change scenarios on soil erosion using CLUE-s and RUSLE models. International Journal of Environmental Science and Technology, 14(9), 1905-1918.

Lu, Y., Wu, P., Ma, X., \& Li, X. (2019). Detection and prediction of land use/land cover change using spatiotemporal data fusion and the Cellular Automata-Markov model. Environmental monitoring and assessment, 191(2), p 66-68.

Eskandari Damaneh, H.,Gholami, Khosravi, H., Mahdavi Najafabadi, R., Khorani, A., Li, G. (2020). Modeling spatial and temporal changes in land-uses and land cover of the Lake Urmia Basin: The application of cellular automata and Markov chain. Geography and Sustainability of Environment. 10(2), p 1-13.

Ni, W., Sun, G., \& Ranson, K. J. (2015). Characterization of ASTER GDEM elevation data over vegetated area compared with lidar data. International Journal of Digital Earth, 8(3), 198-211. 


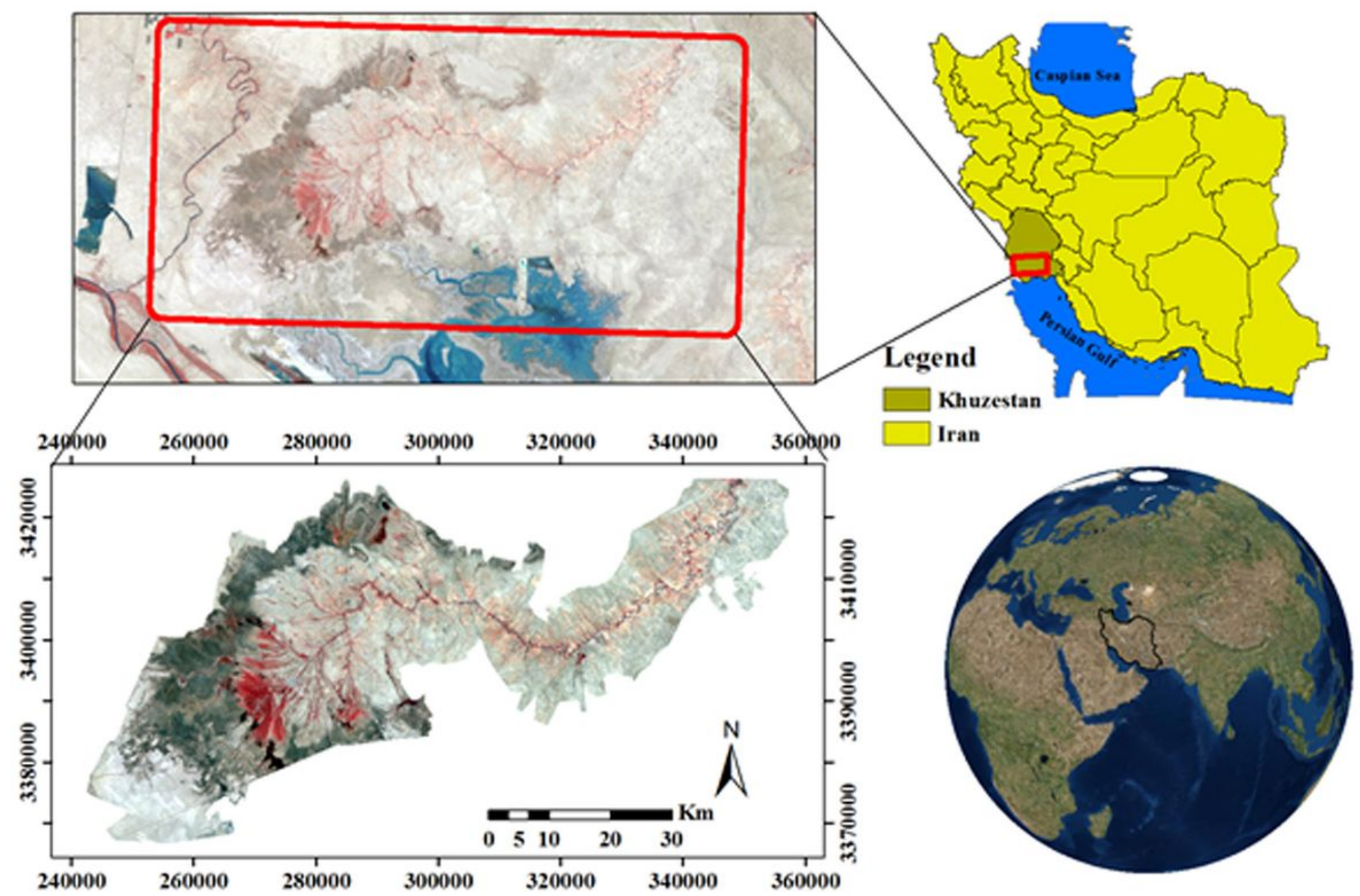

Figure 1

Location of the study area. Note: The designations employed and the presentation of the material on this map do not imply the expression of any opinion whatsoever on the part of Research Square concerning the legal status of any country, territory, city or area or of its authorities, or concerning the delimitation of its frontiers or boundaries. This map has been provided by the authors. 


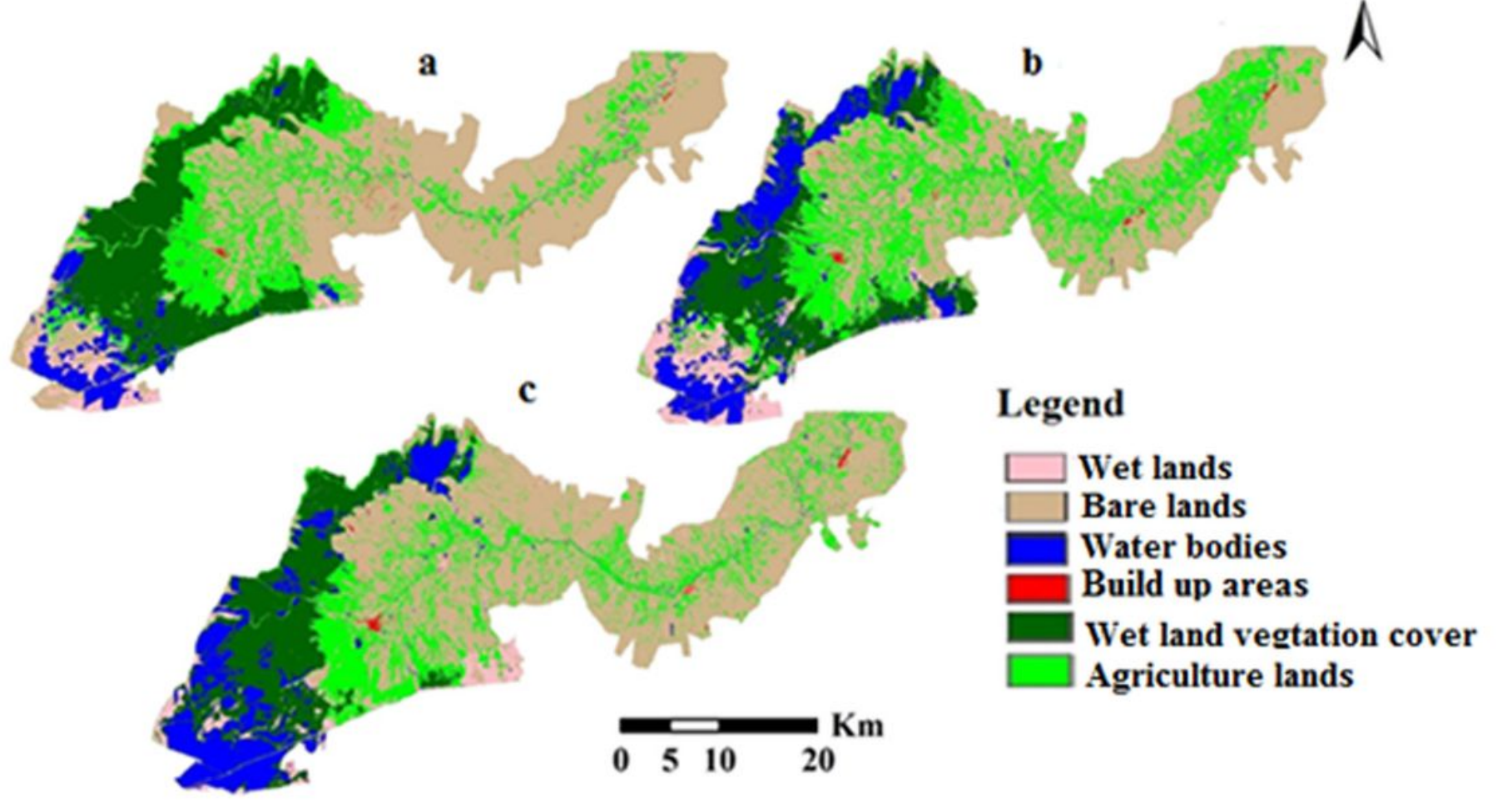

Figure 2

LULC map of 1989(a), 2003(b) and 2017(c). Note: The designations employed and the presentation of the material on this map do not imply the expression of any opinion whatsoever on the part of Research Square concerning the legal status of any country, territory, city or area or of its authorities, or concerning the delimitation of its frontiers or boundaries. This map has been provided by the authors. 


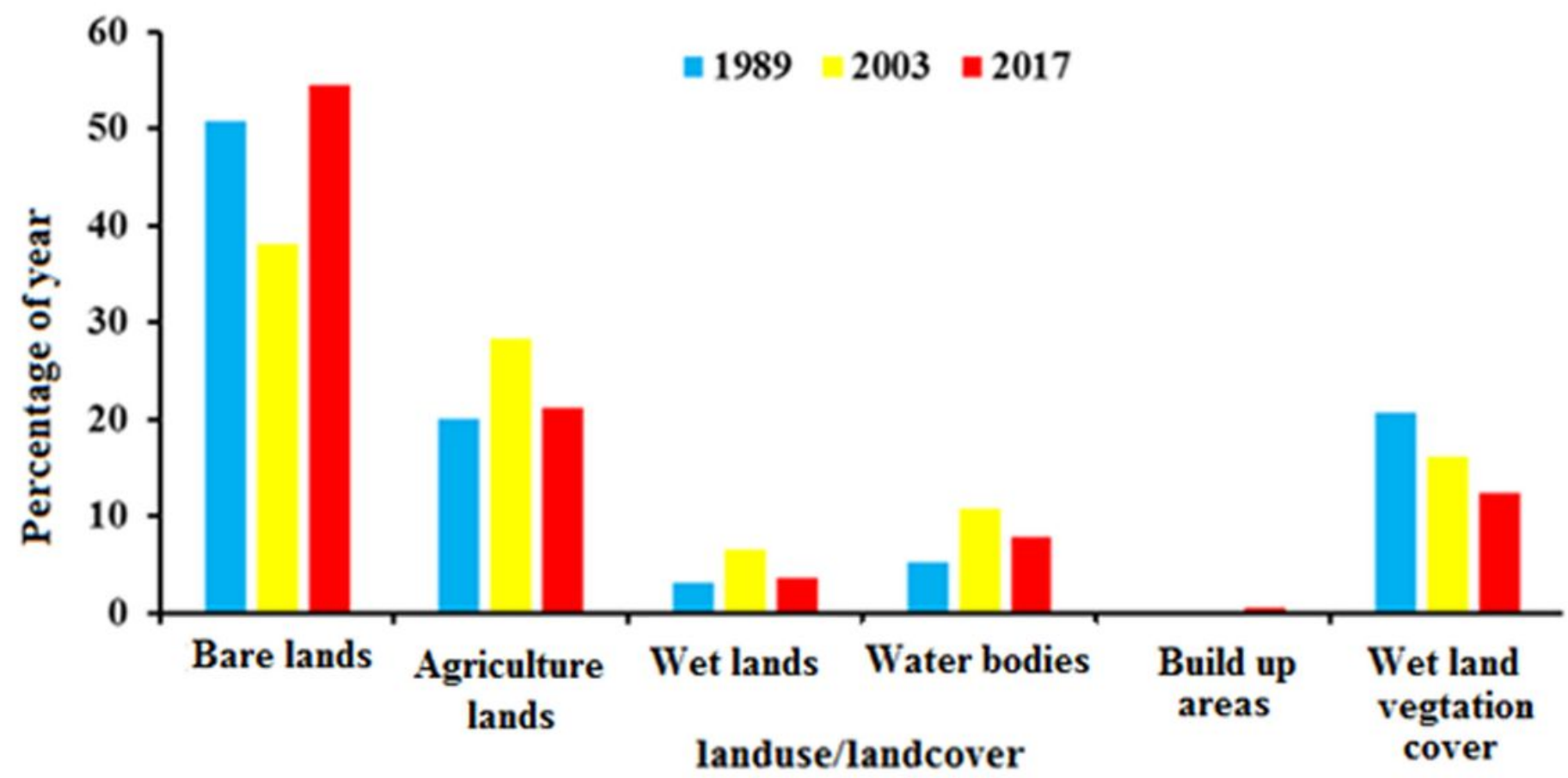

Figure 3

percentage of land use /land cover of the year

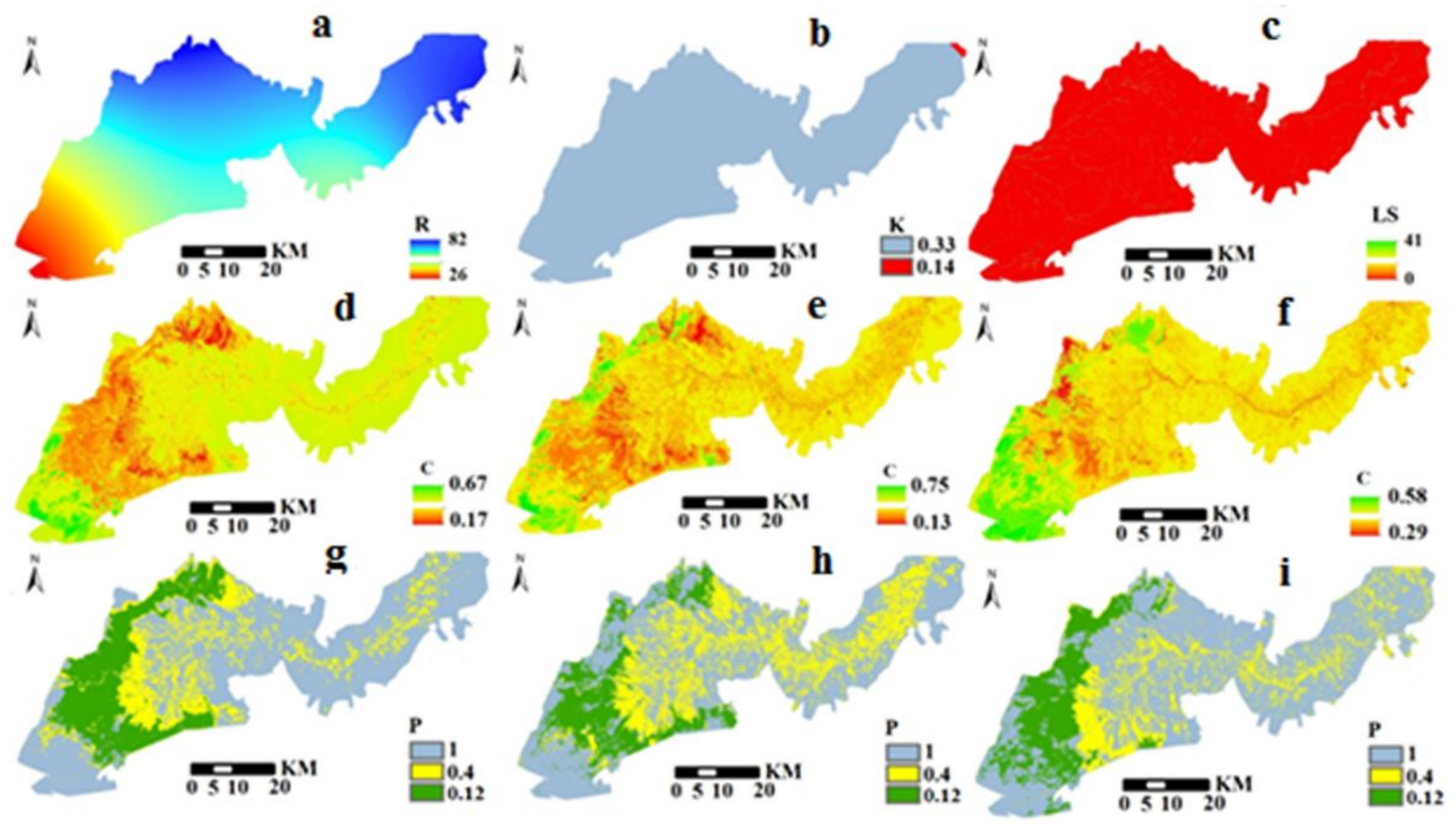




\section{Figure 4}

Maps of a) rainfall erosivity factor, b) soil erodibility factor, c) topographic factor, d) vegetation cover factor for 1989, e) vegetation cover factor for 2003, f) vegetation cover factor for $2017, \mathrm{~g}$ ) conservation support practice factor for $1989, \mathrm{~h}$ ) conservation support practice factor for 2003 , and i) conservation support practice factor for 2017. Note: The designations employed and the presentation of the material on this map do not imply the expression of any opinion whatsoever on the part of Research Square concerning the legal status of any country, territory, city or area or of its authorities, or concerning the delimitation of its frontiers or boundaries. This map has been provided by the authors.

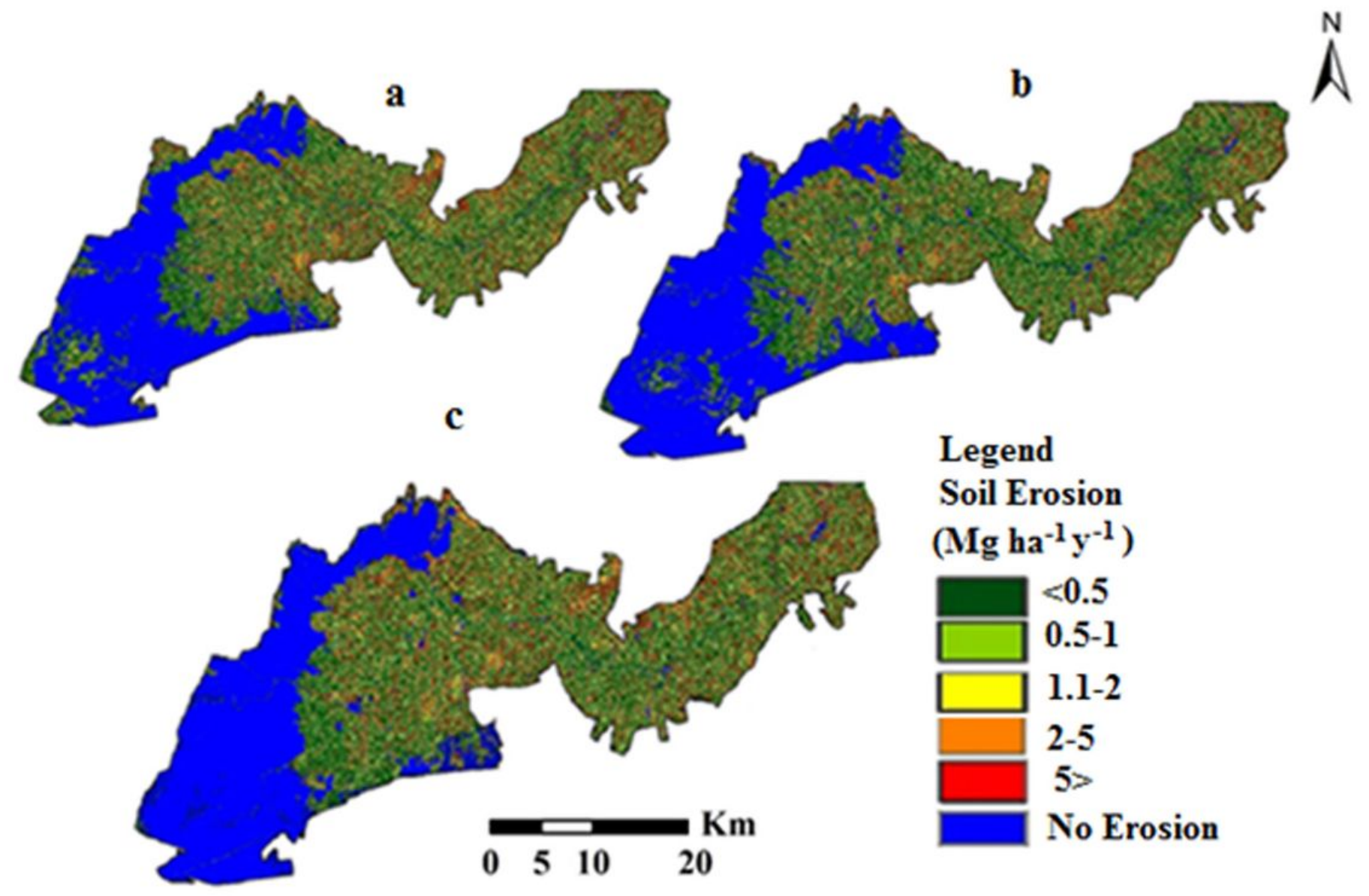

\section{Figure 5}

Soil erosion map for 1989 (a), 2003(b), and 2017(c). Note: The designations employed and the presentation of the material on this map do not imply the expression of any opinion whatsoever on the part of Research Square concerning the legal status of any country, territory, city or area or of its authorities, or concerning the delimitation of its frontiers or boundaries. This map has been provided by the authors. 

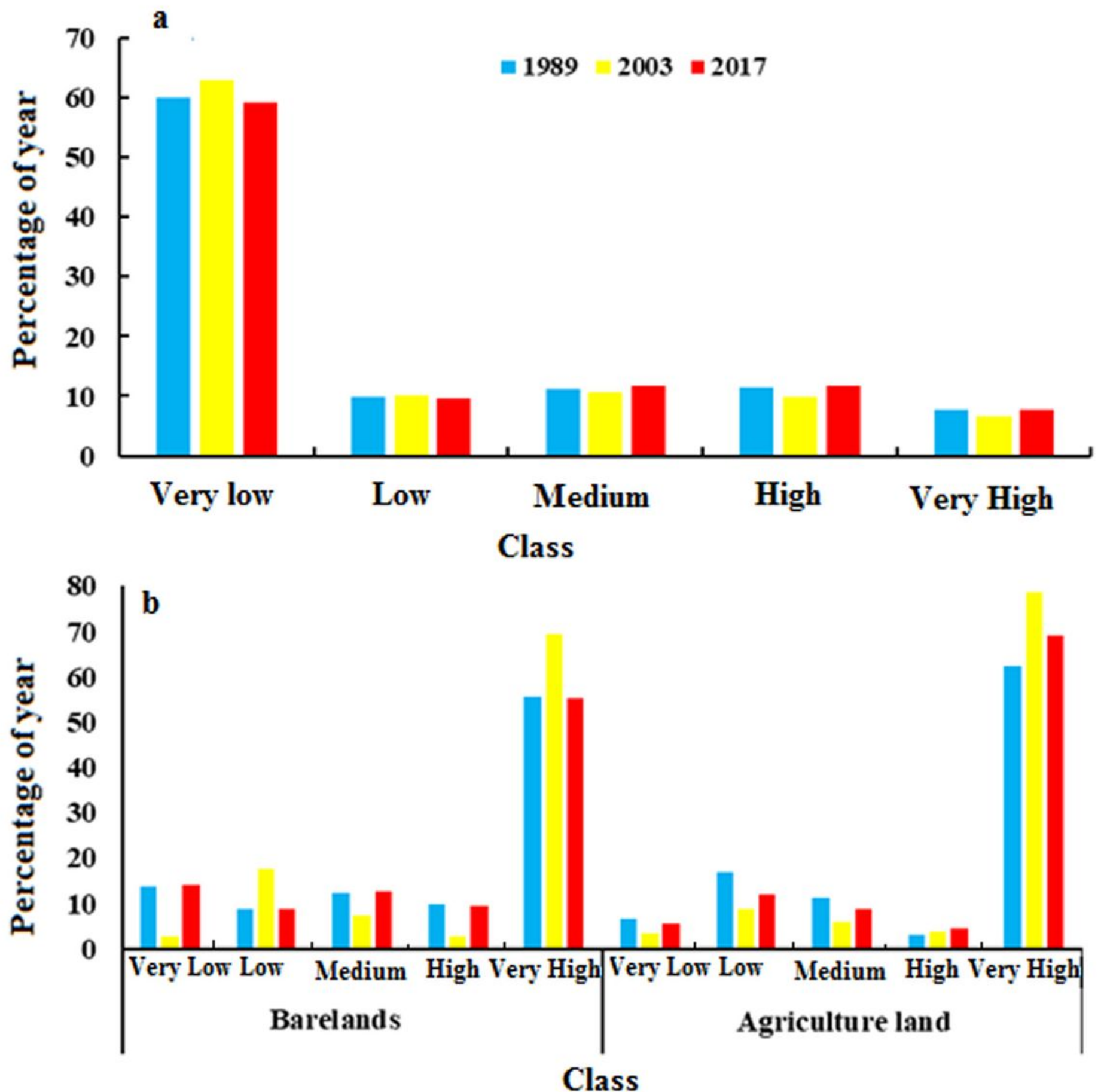

Figure 6

The percentages of the area classified into each soil erosion class (a) and erosion classes for bare land and agricultural land (b). 